\title{
AdDitions to the ARANEOFAUNA OF ANDHRA PRADESH, INDIA - PART II. RECORDS OF INTERESTING SPECIES OF THE COMB-FOOTED GENERA LATRODECTUS, RHOMPHAEA AND COLEOSOMA (ARANEAE: THERIDIIDAE)
}

\author{
C. Srinivasulu ${ }^{1}$, Bhargavi Srinivasulu ${ }^{2}$, S.M. Maqsood Javed ${ }^{3}$, M. Seetharamaraju ${ }^{4}$, \\ S. Asha Jyothi ${ }^{5}$, C. Aditya Srinivasulu ${ }^{6} \&$ Farida Tampal ${ }^{7}$
}

\author{
1,2,4,5 Wildlife Biology Section, Department of Zoology, University College of Science, Osmania University, Hyderabad, \\ Andhra Pradesh 500007, India \\ 3,7 World Wide Fund for Nature-India, APSO, Ho. No. 818, Castle Hills, Road No. 2, Near NMDC, Vijayanagar Colony, \\ Hyderabad 500057, Andhra Pradesh, India \\ ${ }^{6}$ Biodiversity Research and Conservation Society, G4 MRK Towers, Swarnadhamanagar, Old Bowenpally, Secunderabad, \\ Andhra Pradesh 500011, India \\ ${ }^{1}$ hyd2masawa@gmail.com (corresponding author), ${ }^{2}$ bharisrini@gmail.com, ${ }^{3}$ javedbiodiversity@gmail.com, \\ ${ }^{4}$ Iycodont@gmail.com, ${ }^{5}$ ajsirigudi@gmail.com, ${ }^{6}$ juramaia98@gmail.com, ${ }^{7}$ ftampal@wwfindia.net
}

\begin{abstract}
We report three interesting species of comb-footed spiders (Aranaea: Theridiidae) belonging to three different genera, namely, Latrodectus, Rhomphaea and Coleosoma, of which Latrodectus erythromelas is a first record to India, while Rhomphaea projiciens and Coleosoma floridanum are a first record to Andhra Pradesh. We provide the detailed description of Latrodectus erythromelas, Rhomphaea projiciens and Coleosoma floridanum.
\end{abstract}

Keywords: Andhra Pradesh, Aranaea, India, new records, Theridiidae.
The family Theridiidae Sundevall, 1833 is one of the most diverse families of spiders characterized by the presence of a distinct comb on the tarsus of the fourth pair of legs (Levi 1959a). The spiders of this family are kleptoparasitic and araneophagous and build webs of diverse architecture (Exline \& Levi 1962; Elgar 1993; Agnarsson 2004). In India, this family is represented by 43 species (Platnick 2013).

Araneofaunal diversity of Andhra Pradesh is poorly documented with about 120 species documented so far. We have been regularly conducting surveys for documenting the spider diversity since the late 1990s.

DOI: http://dx.doi.org/10.11609/JoTT.o2660.4483-91 | ZooBank: urn:Isid:zoobank.org:pub:3E587D3F-9FFE-42B7-8ABF-A13DB26EFA7C

Editor: Anonymity requested.

Date of publication: 26 June 2013 (online \& print)

Manuscript details: Ms \# 02660 | Received 28 December 2010 | Final received 02 June 2013 | Finally accepted 03 June 2013

Citation: Srinivasulu, C., B. Srinivasulu, S.M.M. Javed, M. Seetharamaraju, S.A. Jyothi, C.A. Srinivasulu \& F. Tampal (2013). Additions to the araneofauna of Andhra Pradesh, India - part II. Records of interesting species of the comb-footed genera Latrodectus, Rhomphaea and Coleosoma (Araneae: Theridiidae). Journal of Threatened Taxa 5(10): 4483-4491; http://dx.doi.org/10.11609/JoTT.02660.4483-91

Copyright: @ Srinivasulu et al. 2013. Creative Commons Attribution 3.0 Unported License. JoTT allows unrestricted use of this article in any medium, reproduction and distribution by providing adequate credit to the authors and the source of publication.

Funding: Department of Biotechnology, Govt. of India, New Delhi; UGC, New Delhi; WWF-India, New Delhi.

Competing Interest: None.
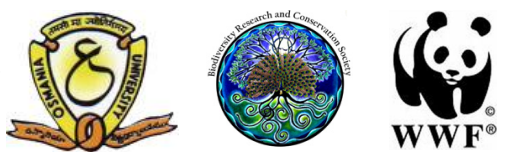

Acknowledgements: The authors are very thankful to Shri Hitesh Malhotra, IFS, former Principal Chief Conservator of Forest (Wildlife) and Chief Wildlife Warden and Shri A.V. Joseph, IFS, Principal Chief Conservator of Forest (Wildlife) and Chief Wildlife Warden, Government of Andhra Pradesh; Dr. R. Hampaiah, Chairman, Dr. V.B. Ramanamurthy IFS, former Member Secretary and Dr. S.N. Jadhav IFS, Member Secretary Andhra Pradesh Biodiversity Board, Govt. of Andhra Pradesh, Hyderabad for constant support and encouragement in biodiversity documentation and studies. We also thank the Head, Department of Zoology, Osmania University, Hyderabad for encouragement and facilities. We are also thankful to Dr. R.J. Raven, Queensland Museum, Brisbane, Australia for identifying the Latrodectus erythromelas and Dr. Peter Jäger, Research Institute and Natural History Museum Senckenberg, Frankfurt, Germany for providing important references. S.M.M. Javed and Farida Tampal express gratitude to Shri Anil Kumar V. Epur, Chairman, WWF-AP State Committee, Hyderabad and Shri Ravi Singh, Secretary General \& CEO, WWF-India, New Delhi for constant support and encouragement. Dr. C. Srinivasulu and Dr. Bhargavi Srinivasulu thank DBT, Government of India and UGC-SAP II Programme, Department of Zoology, Osmania University, Hyderabad for research funding. 
The studies have resulted in the discovery of some hitherto unreported as well as new species of spiders from Andhra Pradesh (Srinivasulu 2000; Rao et al. 2004; Srinivasulu et al. 2004a,b; Rao et al. 2006; Srinivasulu et al. 2008; Javed \& Tampal 2010; Javed et al. 2010a,b). Recently, Javed et al. (2010a) reported the presence of three comb-footed spider species of genus Argyrodes from Andhra Pradesh including a new record for India.

Through this communication we report the presence of an additional three species of comb-footed spiders from Andhra Pradesh, including first specimen-based report of Latrodectus erythromelas and second specimen-based reports of Rhomphaea projiciens and Coleosoma floridanum from India.

\section{Materials and Methods}

Specimens of spiders were collected, following standard techniques, from their natural habitats either from their own webs or from the webs of other spiders. Some specimens were kept live in a terrarium in the Department of Zoology, Osmania University, Hyderabad for observation while others were preserved after photographing them. All specimens were preserved in $70 \%$ ethanol and deposited in the Natural History Museum of Osmania University, Hyderabad, Andhra Pradesh, India. The specimens were examined and measured using a Lawrence and Mayo stereomicroscope. The epigynum and palps were examined and illustrated after being dissected from the spider's body. Internal epigynum was cleared in $\mathrm{KOH}$ solution to dissolve nonchitinous tissue. The ultra structures were observed under a compound microscope. All measurements are in millimeters.

\section{Results and Discussion}

Four specimens, including three females (one of Latrodectus erythromelas and two of Rhomphaea projiciens) and one male (of Coleosoma floridanum) form the basis of the descriptions provided below. Diagnostic characters of the genera and detailed description of the species based on specimens collected from Andhra Pradesh have been provided below. With respect to Latrodectus erythromelas, as there exists no English description of this species (the type description being in German), we provide the English description of the species for ease in identification of specimens yet to be collected from elsewhere, both based on type description as well as observations of the Indian specimen.

\section{Genus Latrodectus Walckenaer, 1805}

Diagnosis: Carapace, normal in form, with clypeus equal in height to the ocular area, and the lateral eyes being widely separated. Chelicerae lack teeth. Legs long, superior claws toothed almost to apex. First pair of legs longer than the fourth pair. Abdomen globose; colulus large. Males much smaller than females. Female genitalia with dumb-bell-shaped seminal vesicles (Levi 1959a; Levi \& Randolph 1975).

\section{Latrodectus erythromelas Schmidt \& Klaas, 1991}

Diagnosis: Latrodectus erythromelas can be distinguished from other species of the Latrodectus mactans group by conspicuously lacking the hourglass marking on the ventral side of the abdomen, a character also seen in Latrodectus cinctus from which it can be distinguished by a relatively short and broader red dorsal stripe (Schmidt \& Klaas 1991).

\section{Description of the female specimen of Latrodectus erythromelas Schmidt \& Klaas, 1991 from Andhra Pradesh}

Material examined: NHM.OU.SPI.3-2007, 1 female, 2.xii.2007, $17^{\circ} 20^{\prime} \mathrm{N} \& 7^{\circ} 30^{\prime} \mathrm{E}$, Meerpur, Hyderabad, Andhra Pradesh, India, coll. M. Seetharamaraju, Osmania University Natural History Museum, Hyderabad.

Description: Female: Carapace black, rounded and convex, rather high, covered with fine hair. Ocular area darker, occupies almost anterior one-fourth of carapace length, vicinity of eyes almost black with blackishred margins. Clypeus as high as ocular area, eyes two rows, slightly recurved. Maxillae, labium, sternum and chelicerae black. Abdomen globular, black, covered with fine hair; dorsally bearing a red band (Image 1A) that spans from the middle of the abdomen to the ventral side reaching up to the spinnerets that is again black, black fine hair on the red band detectable; ventrally the abdomen is black throughout in live condition, but some faint red spotting (Image 1B), one just next to spinnerets and a pair midway the abdomen, can be detected in preserved specimen, a character that matches with the type description (Schmidt \& Klaas 1991). Legs long and thin, black throughout, first pair longest (with very long tibiae). Leg hairs black. Legs I, IV, II, III. The body measurements of the Indian specimen along with the Sri Lankan specimens are given in Table 1.

Male (after Schmidt \& Klaas 1991): Cephalothorax, abdomen and spinnerets black. Eyes in two distinct slightly recurved rows. On the dorsal side of the abdomen five pairs of white spots, of which the last two pairs joining each other, is present. Legs long and thin, 


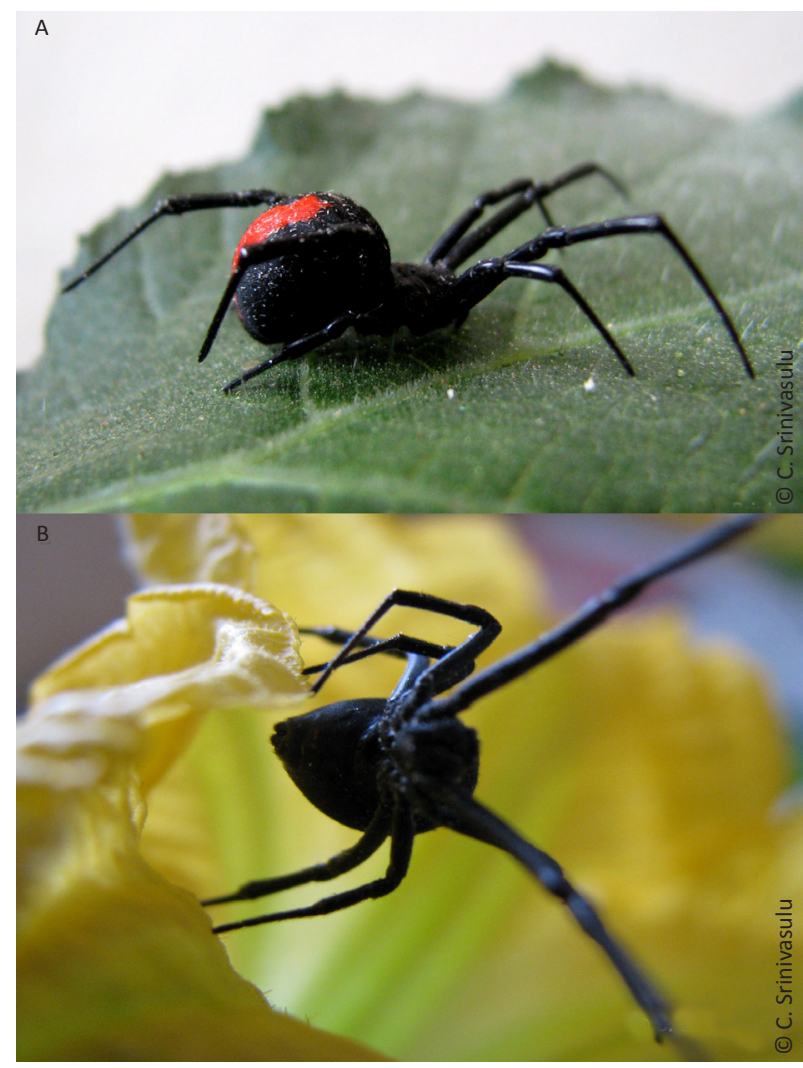

Image 1. Habit of Latrodectus erythromelas from India, A - Dorsal view of the spider showing short and broad red stripe; B - View of the ventral aspect of abdomen conspicuously lacking the 'hourglass' marking

trochanter, femur, patella and tibia of legs I, II, and IV dark brown, while Leg III russet; all metatarsi and tarsi russet. Leg hairs black. Legs I, IV, II, III. Embolus with three turns, cymbium extends up to $0.44 \mathrm{~mm}$.

Remarks: The members of the genus Latrodectus Walckenaer, 1805 are notorious for their potent neurotoxin as well as the mate-devouring behavior of the females. As many as 31 species belong to the genus Latrodectus, and many of these are cosmopolitan occurring on multiple continents and oceanic islands (Platnick 2013). Some taxa like Latrodectus mactans (Fabricius, 1775) (Black Widow Spider of North America and West Indies), Latrodectus hasselti (Thorell, 1870) (Red-back Spider of Australia, New Zealand and South east and south Asia), Latrodectus geometricus (C.L. Koch, 1841) (Brown Widow Spider of Africa and Asia) are well known. In colonial times, two species - Latrodectus hasselti and Latrodectus geometricus were reported from British India basing on forms collected from the vicinity of the present day Karachi, Pakistan and Myanmar (Pocock 1900). Latrodectus hasselti had been till recently the only known widow spider occurring in
Table 1. Body measurements of Indian specimen of Latrodectus erythromelas in comparison with the Sri Lankan specimens Latrodectus erythromelas (after Schmidt \& Klaas, 1991)

\begin{tabular}{|l|c|c|}
\hline Character & \multicolumn{2}{|c|}{ Measurement (in mm) } \\
\hline & Indian & Sri Lankan \\
\hline Total Body Length & 8.8 & $5.5-9.0^{*}$ \\
\hline Carapace Length & 3.1 & $2.0-3.0^{*}$ \\
\hline Abdomen Length & 5.7 & $3.5-6.0^{*}$ \\
\hline "Leg I (Total) & & \\
\hline Femur & 4.0 & 3.9 \\
\hline Patella \& Tibia & 4.6 & 4.0 \\
\hline Metatarsus & 4.0 & 4.0 \\
\hline Tarsus & 1.5 & 1.2 \\
\hline Leg IV (Total) & & \\
\hline Femur & 3.5 & 2.8 \\
\hline Patella \& Tibia & 2.6 & 2.7 \\
\hline Metatarsus & 2.6 & 2.5 \\
\hline Tarsus & 1.2 & 1.0 \\
\hline
\end{tabular}

( ${ }^{*}$ range for body measurements based on five specimens, \# - average leg measurements)

India reported from Pune and Thane in Maharashtra, Vadodra in Gujarat, Coimbatore in Tamil Nadu and Nannaj in Maharashtra (Daniel \& Soman 1961; Tikader 1987; Siliwal \& Kumar 2001; Kumar \& Siliwal 2005; Siliwal \& Molur 2007; Hippargi et al. 2012). With a recent report of occurrence of Latrodectus geometricus from Pune, Maharashtra (Shukla \& Gour-Broome 2007) and Latrodectus elegans from Thawai, Manipur (Kananbala et al. 2012), two more species for this genus have been added to spider diversity in India. The locality records of all these three species are restricted to the hill ranges of western India ranging from Gujarat to Tamil Nadu and Eastern Himalaya (Image 2), excepting that of L. hasselti and $L$. erythromelas that have been reported also from the Deccan Plateau.

Very little is known about the biology of Latrodectus erythromelas in the wild and so far it has been known only from the type locality. The present specimen was collected from an untidy and unkempt three-dimensional web about two feet above ground level, positioned on the underside of the web in a relatively undisturbed area of human habitation in Hyderabad City. The vegetation of Hyderabad is basically of the dry deciduous thorny scrub forest type, most of which has been replaced by gardens consisting of exotic ornamentals. The spider did not exhibit any aggressive behavior when handled. In captivity, the spider was observed to construct its characteristic web and spent most of its time in the 


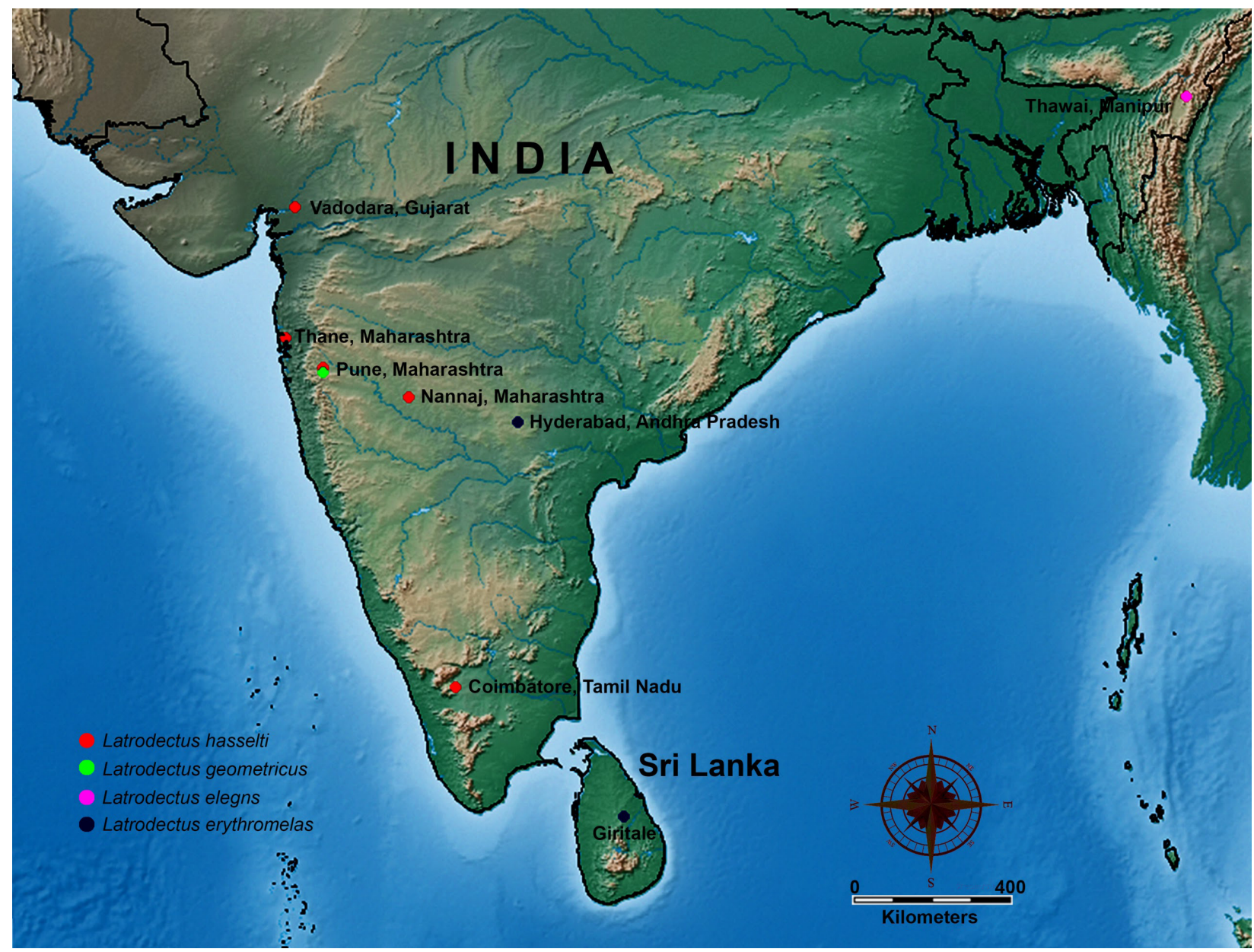

Image 2. Distribution of Latrodectus spp. in India

centre of the web in an inverted position. It was fed Blatella germanica, Musca domestica and moths. It preferred to feed in privacy and it was observed to draw close the first pair of legs before starting to capture and feed on its prey.

The types of Latrodectus erythromelas Schmidt \& Klaas, 1991 were collected from the vicinity of Giritale, Sri Lanka in the dry deciduous forest on a small promontory with an average of $40^{\circ} \mathrm{C}$ summer temperature with 60$70 \%$ relative humidity. Hyderabad, India also enjoys a similar climate and we feel that the widow spiders could be more widely distributed in India than assumed and careful surveys would yield further site records. Knowledge about spider species that have the potential of causing human fatalities would go a long way in avoiding negative spider-human interactions and would help in saving human lives by education campaigns and development of antivenins to treat latrotoxins.

The present report of Latrodectus erythromelas Schmidt \& Klaas, 1991 from Hyderabad, Andhra Pradesh,
India extends the known range of this species outside Sri Lanka northward by ca. 1000 km (Image 2).

\section{Genus Rhomphaea L. Koch, 1872}

Diagnosis: The genus Rhomphaea is characterized by the following diagnostic characters (after Yoshida 2001): Carapace usually with a projection of eye region in male; clypeus slanting and projecting anteriorly in both sexes. Female abdomen tapering to a single tip, usually four to six times as long behind as anterior to spinnerets. Epigynum with a ventrally membranous projection, a depression and openings situated in front of it. Conductor of male palpus membranous; tip of embolus thin and clockwise (left palpus) with large base. Legs thin and long: first patella and tibia 1.5 to 2.1 times the fourth, 3.0 to 3.9 times the carapace length.

\section{Rhomphaea projiciens O.P.-Cambridge, 1896}

Diagnosis: Rhomphaea projiciens O.P.-Cambridge, 1896 can be distinguished from other species of 
Rhomphaeagenusbyconspicuouslypossessingelongated tapering abdomen possessing a long sclerotized spine (Exline \& Levi 1962).

\section{Description of the female specimens of Rhomphaea projiciens O.P.-Cambridge, 1896 from Andhra Pradesh}

Materials examined: NHM.OU.SPI.2-2008, 1 female, 09.xi.2008, $16^{0} 19^{\prime} \mathrm{N} \& 77^{\circ} 49^{\prime} \mathrm{E}$, Ookachetipalem Vagu, Ramanpadu Village, Kothakota Mandal, Mahbubnagar District, Andhra Pradesh, India, coll. C. Aditya Srinivasulu and Bhargavi Srinivasulu, Osmania University Natural History Museum, Hyderabad; NHM.OU.SPI.10-2009, 1 female, 03.i.2009, $17^{\circ} 25^{\prime} \mathrm{N} \& 78^{\circ} 31^{\prime} \mathrm{E}$, Osmania University Campus, Hyderabad, Andhra Pradesh, India, coll. C. Srinivasulu and S.M. Maqsood Javed, Osmania University Natural History Museum, Hyderabad.

Description: Small comb-footed spider with long and tapering abdomen (Image $3 \mathrm{~A}$ ); less than 7.8 (total length with cephalothorax and abdomen lengths in straight line). Total length 7.8, 7.5; cephalothorax 1.4, 1.3; abdomen 6.4, 6.2. Cephalothorax pale yellow, longer than wide (Image $3 \mathrm{~A}$ ). Thoracic part with irregular grey band on each side. Carapace slightly raised beyond thoracic groove. Median ocular quad small located on a low tubercle. Eyes small, anterior median eyes larger than others, contiguous with anterior lateral eyes; posterior median eyes separated by about a diameter and close to posterior lateral eyes. Clypeus straight, slanting a little forward and a little higher than the length of the chelicerae. Sternum longer than wide, pale with irregular brownish lateral bands almost join anteriorly and join completely posteriorly. Abdomen slender, pale with brownish streaks on venter and around spinnerets (Fig. 1A \& B; Image $3 \mathrm{~A}$; Image 4 B \& C), anterior part

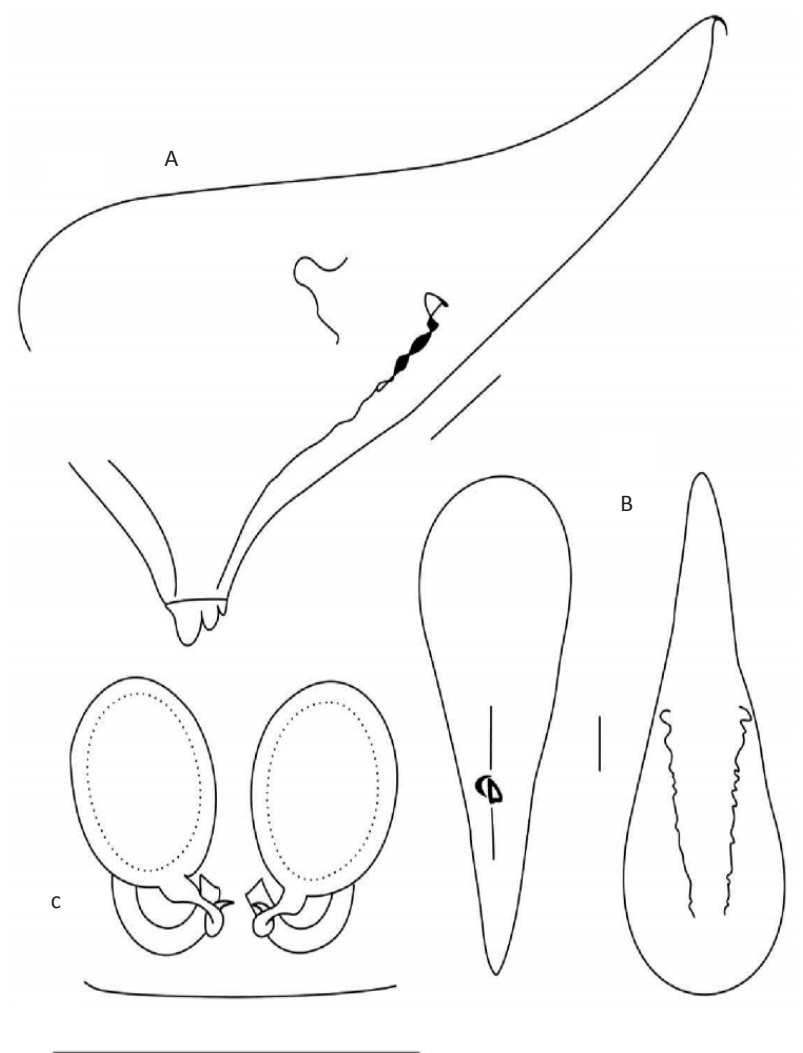

Figure 1. Rhomphaea projiciens from Andhra Pradesh.

A - Lateral view of the abdomen; B - Dorsal and ventral view of the abdomen; C - Internal epigynum [scale A \& B - 0.5mm; C - 1mm]

of the abdomen paler than the posterior part which is clearly covered with irregular silvery spots and also the two zones are clearly demarcated by dark brown streak (Fig. 1A \& B; Image $3 \mathrm{~A}$; Image $4 \mathrm{~B} \& C$ ); far more than twice as long as wide (Fig. 1A; Image 3 A\&B; Image 4 $B \& C)$, constricted posterior to middle (Image $4 \mathrm{~B}$ ), and
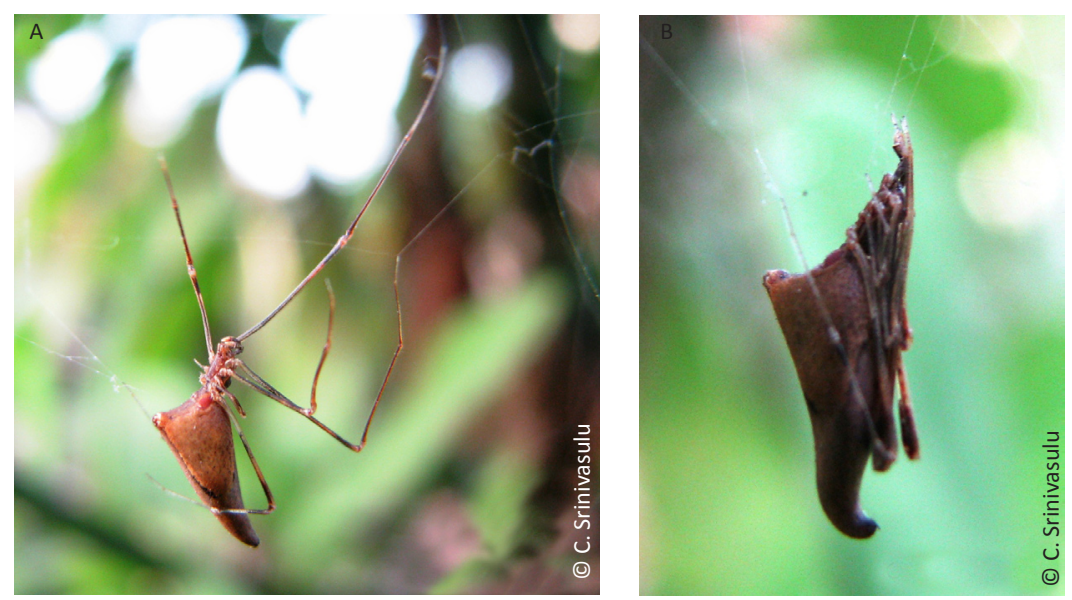

Image 3. Habit of Rhomphaea projiciens from India.

A - Female (live); b - Retracted posture of disturbed female, note the sclerotized spine at the posterior end of the abdomen 
tapering posteriorly (Image $4 \mathrm{C}$ ) with wrinkled tip (Image 4 C\&D), bluntly rounded with a long sclerotized spine (Fig. 1A; Image 4 D). Spinnerets closely set (Image 4 $E$ ) and located on a mound closer to stalk (Image $3 \mathrm{~A}$, $B$; Image 4 F). Legs thin and long, thickly covered with hair-like setae. Legs and palpi pale irregularly annulated with light brown and streaked with reddish longitudinal lines and spots (Image $3 \mathrm{~A}$ ). The external epigynum is slightly swollen and does not reach the genital groove, the genital openings are indistinct and somewhat distantly placed and clearly lack the scelrotized margins or plate. The internal epigynum is simple with globular seminal receptacles and simple and weakly sclerotized connecting tubes (Fig. 1C).

Remarks: The spiders of the genus Rhomphaea $\mathrm{L}$. Koch, 1872 are typical comb-footed spiders that are characterized by a very elongated tapering abdomen usually tipped by a single or two spines. Like Argyrodes species (one of the genus belonging to subfamily Argyrodinae Simon, 1894), species belonging to genus Rhomphaea may live in host webs without constructing any webs of their own, but often they add fine lines between the spirals of an orb-web, and occasionally they live independently, making their own small theridiid webs (Exline \& Levi 1962). Prior to Yoshida (2001), the genus Rhomphaea, all species attributed to 'Rhomphaea' group (by Exline \& Levi 1962) was treated under Argyrodes (Arnedo et al. 2004). Presently as many as 33 extant species belong to this genus (Platnick 2013).

The genus Rhomphaea, represented by $R$. projiciens O.P.-Cambridge, 1896, is known from India based on a few specimens collected from Gujarat and Kerala (Patel 1973; Patel 2003a,b). Although, Patel (2003b) provides the nomen $R$. vansdaensis to specimens collected from Parambikulam Wildlife Sanctuary, Kerala [possibly given to specimens collected by him in Vansda National Park, Gujarat (Patel 2003a)], we could not locate the full description of the said species, thus, like Siliwal et al. (2005), Siliwal \& Molur (2007) and Platnick (2013), we do not consider $R$. vansdaensis a valid species pending clarification on its taxonomic status.

Both the specimens were collected from the webs of Argiope species. When disturbed the spider

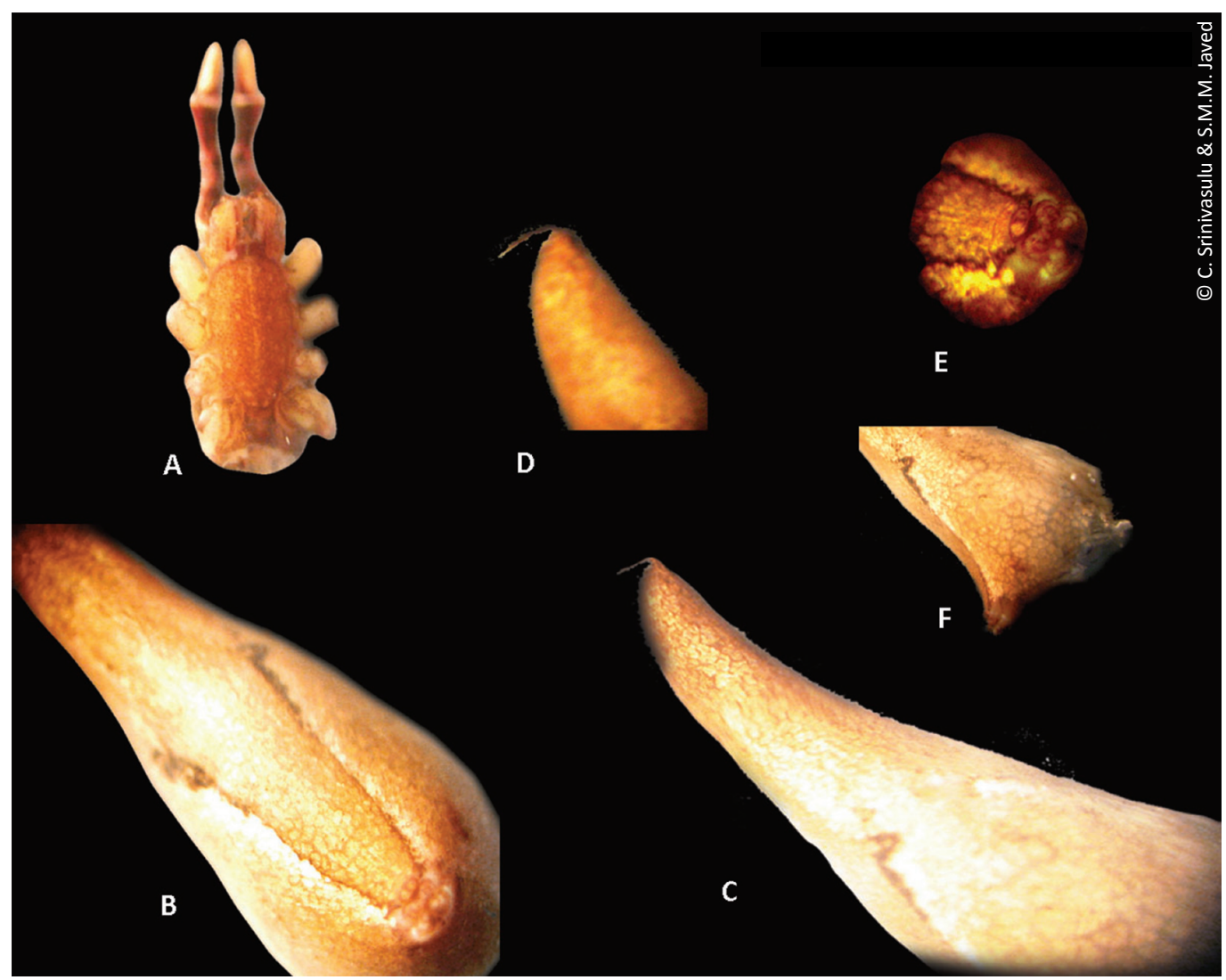

Image 4. Rhomphaea projiciens from India.

A - Cephalothorax; B - Ventral aspect of the abdomen; C - Lateral aspect of the abdomen; D - Posterior end of the abdomen showing sclerotized spine; E - Spinnerets; F - Lateral aspect of the abdomen showing position of spinnerets 
retracts its body and legs to imitate dry leaf (Image 3 B). Like the silverdew spiders of genus Argyrodes one of the specimens displayed drop down behavior when disturbed.

\section{Genus Coleosoma O.P.-Cambridge, 1882}

Diagnosis: The genus Coleosoma is characterized by the following diagnostic characters (after Cambridge 1882 fide Byrant 1944): Small, less than $3 \mathrm{~mm}$ total length. Cephalothorax, longer than broad, moderately convex, slopping gradually from eye area to posterior margin, thoracic groove punctiformis. Eyes small, anterior row recurved, eyes subequal and equidistant, posterior row procurved, lateral eyes touching. Chelicerae bear zero to one tooth in promargin. Clypeus very high, convex; mandibles vertical, small and weak; labium wider than long; maxillae narrow, inclined over labium. Legs, in males I and IV longest, in females I and II longest; tarsal comb is present, but hardly visible. Abdomen, always modified in males being long, usually constricted in the middle, with a thin bilobed chitinized or scelrotized ring or scutum at the anterior end that extends onto cephalothorax and continues on the venter top about the middle of the abdomen; less modified, essentially cylindrical, or produced in a tubercle above the spinnerets and distinctly lacking the chitinized or sclerotized plate. Colulus absent, male pedipalp bears a functional median apophysis, weakly sclerotized conductor, sclerotized radix and a thin thread-shaped embolus. Epigyne poorly sclerotized without clear orifices.

\section{Coleosoma floridanum (Banks, 1900)}

Diagnosis: Coleosoma floridanum (Banks, 1900) can be distinguished from other species of Coleosoma genus by conspicuously possessing incomplete embolus in males and simple epigynum (Banks 1900; Byrant 1944).

\section{Description of the male specimen of Coleosoma floridanum (Banks, 1900) from Andhra Pradesh}

Material examined: OU.SPI.9-2009, 1 male (Image 5), 28.xii.2009, $18^{\circ} 29^{\prime} \mathrm{N} \& 84^{\circ} 16^{\prime} \mathrm{E}$, seashore of Meghavaram Village, Srikakulam District, Andhra Pradesh, India, coll. C. Srinivasulu, NHM. Osmania University Natural History Museum, Hyderabad.

Description: Small ant-mimic comb-footed spider; less than 2.4, Cephalothorax 0.7, abdomen 1.6. Cephalothorax brown, about two-thirds as wide as long, anterior and posterior margins about equal in width, sides evenly rounded, rather flat slopes gradually from eye area to posterior margin, two small dark lobes near

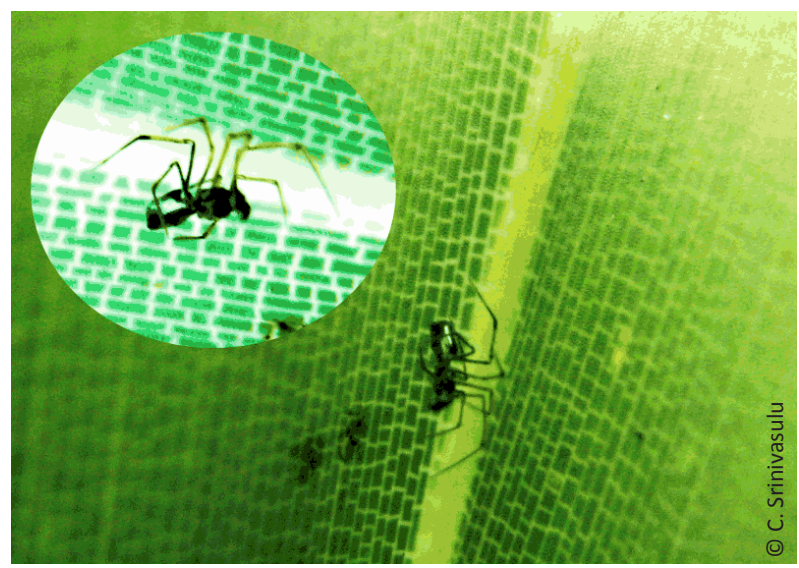

Image 5. Coleosoma floridanum (Banks, 1900), male (live) from Meghavaram, Srikakulam District, Andhra Pradesh

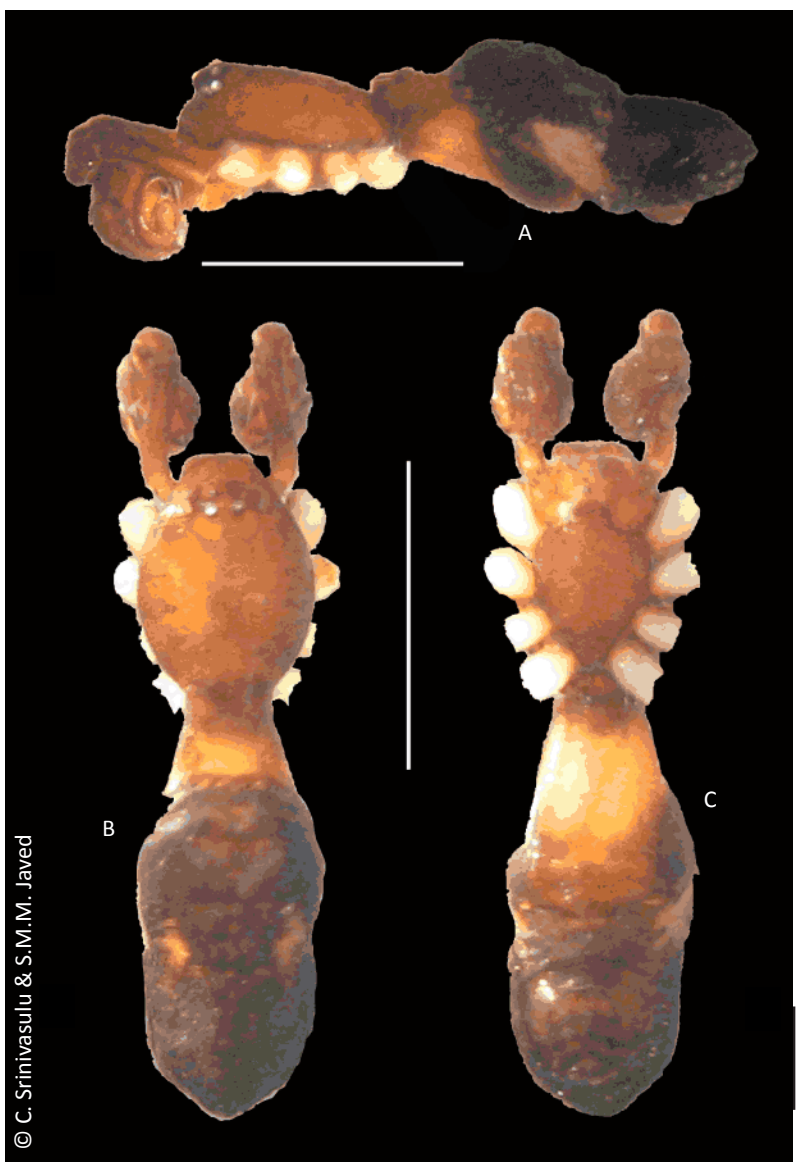

Images 6. Coleosoma floridanum male (preserved specimen). A - Lateral view; B - Dorsal view; C - Ventral view (scale 1mm)

posterior margin, thoracic groove punctiform (Image $6 \mathrm{~A})$. Eyes almost perpendicular in line with anterior margin of the cephalothorax (Image 6A), anterior row slightly recurved, eyes equidistant, anterior median eye smallest, posterior row straight, lateral eyes touching low 


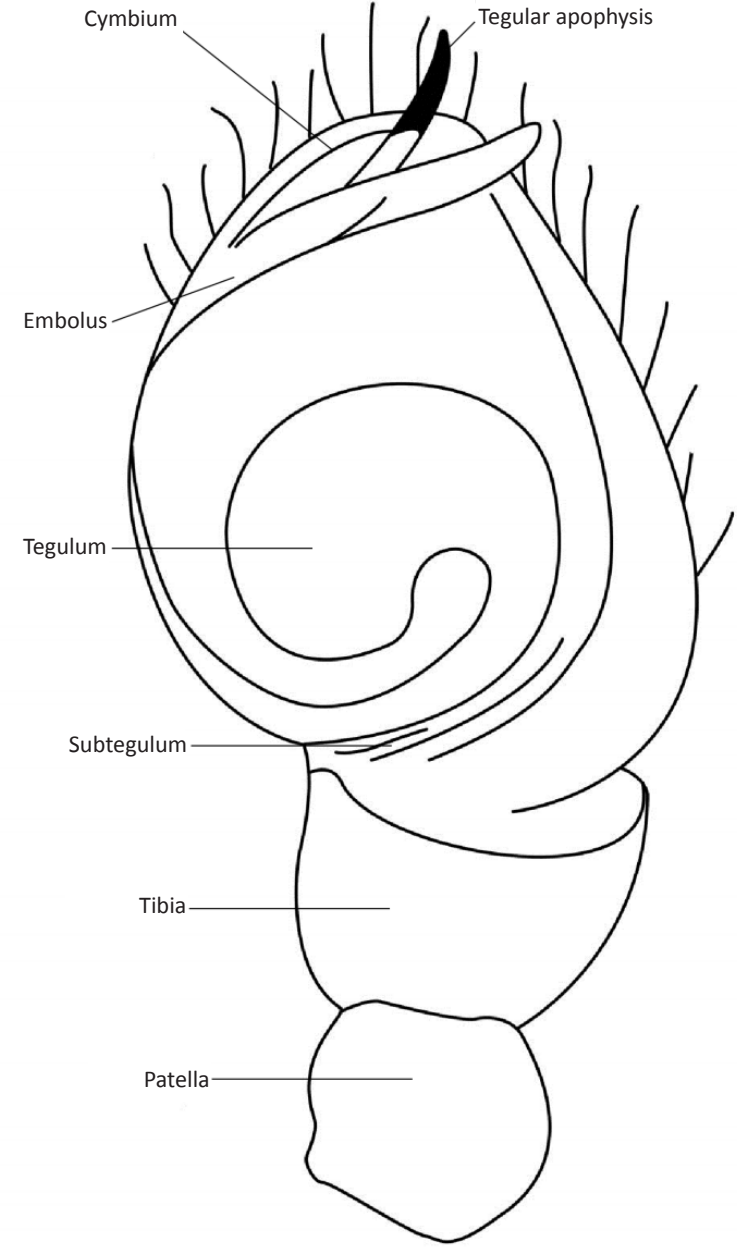

Figure 2. Left palpus of Coleosoma floridanum from Andhra Pradesh

on tubercles. Ocular quad narrow in front and as high as wide behind. Clypeus vertical, slightly convex, with a groove below anterior eye row, about twice as high as the eye area. Mandibles vertical, small, weak. Labium wider than long, fused to sternum (Image 6C). Maxillae twice as long a labium, inclined but tips not touching. Sternum as wide as long, convex, dark about margins (Image 6C). Abdomen more than twice as long as wide (Image 6B), constricted posterior to middle (Image 6A), anterior portion largest, pale brown with lateral dark stripes which end before the constriction (Image 6A), a pair of irregular cream-colour blotches on posterior slopes (Image 6A), constriction pale, posterior portion black with no markings, at the base a thin chitinized or sclerotized plate or sheath that extends into two blunt points over cephalothorax (Image 6B) and extends on the venter to the fold which is posterior to middle (Image 6C). Venter pale. Legs I, IV, II, III. Palpus, not as long as cephalothorax, pale, embolus short, starts from near base and completes about half a circle, the dark piece at the tip quite narrow (Image 6A, Fig. 2), extends beyond the cavity.

Remarks: The members of the genus Coleosoma O.P.-Cambridge, 1882 are the ant-mimic comb-footed spiders. Unlike other theridiids, comb on the tarsus of the fourth pair of legs are indistinct in the species belonging to the genus Coleosoma O.P.-Cambridge, 1882. Nearly 10 species belonging to the genus Coleosoma O.P.Cambridge, 1882 are recognized, of which $C$. blandum O.P.-Cambridge, 1882 and C. floridanum (Banks, 1900) are widespread species, while $C$. acutiventer (Keyserling, 1884) and C. normale Byrant, 1944 are restricted to the new world (from United States of America to Brazil), and the others are restricted to a few locations in Africa and southeast Asia, excepting C. octomaculatum (Bosenberg \& Strand, 1906) that occurs in eastern China, Korea, Taiwan and Japan. Recently discovered and described restricted range species include - $C$. africanum Schmidt \& Krause, 1995 from Cape Verde Islands, and C. caliothripsum Barrion \& Litsinger, 1995, C. pabiogum Barrion \& Litsinger, 1995 and C. pseudoblandum Barrion \& Litsinger, 1995 from the Philippines (Platnick 2013).

Siliwal et al. (2005) and Siliwal \& Molur (2007) have inadvertently missed including the genus Coleosoma O.P.-Cambridge, 1882 as occurring in India or South Asia which gave the scope to Sebastian et al. (2009) to lay claim of first report of this genus from India. The genus Coleosoma was based by O.P.-Cambridge in 1882 on the species blandum known only from the type from Ceylon (present Sri Lanka) (Cambridge 1882; Byrant 1944; Levi 1959b; Platnick 2013) and has already been reported from India by Levi (1959b), based on a specimen of Coleosoma floridanum (Banks, 1900), collected in Honolulu on the cargo of plants coming from Calcutta (now Kolkata).

The vegetation of the seashore at Meghavaram Village is basically of the shoreline scrub type with Borassus flabellifer, Pandanus odoratissmus and Ipomea species. We observed the specimen retreated into an untidy and unkempt web constructed in the fold of a leaf of Borassus flabellifer. When disturbed it came out and moved along the groove of the leaf. It was also observed to feed on small black ants that were numerous on the plant.

\section{REFERENCES}

Agnarsson, I. (2004). Morphological phylogeny of cobweb spiders and their relatives (Araneae, Araneoidea, Theridiidae). Zoological Journal of the Linnean Society 141: 447-626; http://dx.doi.org/ 10.1111/j.1096-3642.2004.00120.x 
Arnedo, M.A., J. Coddington, I. Agnarsson \& R.G. Gillespie (2004) From a comb to a tree: phylogenetic relationships of the Combfooted Spiders (Araneae, Theridiidae) inferred from nuclear and mitochondrial genes. Molecular Phylogenetics and Evolution 31: 225-245.

Banks, N. (1900). New North American spiders. Canadian Entomology 32: 96-102.

Byrant, E.B. (1944). Three species of Coleosoma from Florida (Araneae: Theridiidae). Psyche 51: 51-58.

Cambridge, O.P. (1882). New Araneidea. Proceedings of the Zoological Society of London 1882: 428-442.

Daniel, J.C. \& P.W. Soman (1961). Observations on the spider Latrodectus hasseltii indicus Simon with a note on arachnidism. Journal of the Bombay Natural History Society 58: 823-826.

Elgar, M.A. (1993). Inter-specific associations involving spiders: kleptoparasitism, mimicry and mutualism. Memoirs of the Queensland Museum 33: 411-430.

Exline, H. \& H.W. Levi. (1962). American spiders of the genus Argyrodes (Araneae, Theridiidae). Bulletin of the Museum of Comparative Zoology (Harvard) 127: 73-204.

Kumar, M.G. \& M. Siliwal (2005). Range extension of Latrodectus hasselti Thorell, 1870 (Araneae: Theridiidae). Zoos' Print Journal 20(11): 2072; http://dx.doi.org/10.11609/JoTT.ZPJ.1344.2072

Hippargi, R.V., P.M. Bolde, S.V. Manthen \& A.R. Shaikh (2012). Ecology of venomous spider Latrodectus hasselti Thorell, 1870 (Araneae: Theridiidae) from Solapur and Osmanabad District, Maharashtra. Indian Journal of Arachnology 1(1): 169-174.

Javed, S.M.M. \& F. Tampal (2010). Spiders of the Genus Murricia Simon, 1882 (Araneae: Hersiliidae) from India. Acta Zoologica Lituanica 20(2): 88-97; http://dx.doi.org/10.2478/v10043-010-0012-9

Javed, S.M.M., C. Srinivasulu \& F. Tampal (2010a). Addition to araneofauna of Andhra Pradesh, India: Occurrence of three species of Argyrodes Simon, 1864 (Araneae: Theridiidae). Journal of Threatened Taxa 2(6): 980-985; http://dx.doi.org/10.11609/JoTT. o2194.980-5

Javed, S.M.M., S.H. Foord \& F. Tampal (2010b). A new species of Hersilia Audouin, 1826 (Araneae: Hersiliidae) from India, with notes on its natural history. Zootaxa 2613: 40-50.

Kananbala, A., K. Manoj, M. Bhubaneshwari, A. Binarani \& M. Siliwal (2012). The first report of the widow spider Latrodectus elegans (Araneae: Theridiidae) from India. Journal of Threatened Taxa 4(7): 2718-2722; http://dx.doi.org/10.11609/JoTT.o3152.2718-22

Levi, H.W. (1959a). The spider genus Latrodectus (Araneae, Theridiidae). Transactions of the American Microscopical Society 78: 7-43.

Levi, H.W. (1959b). The spider genus Coleosoma (Araneae: Theridiidae) Breviora, Museum of Comparative Zoology 110: 1-8.

Levi, H.W. \& D.E. Randolph (1975). A key and checklist of American spiders of the family Theridiidae north of Mexico (Araneae). Journal of Arachnology 3: 31-51.

Patel, B.H. (1973). Some interesting Theridiid spiders (Araneae: Theridiidae) from Gujarat, India. Bulletin of International Arachnological Society 2: 149-152.

Patel, B.H. (2003a). Fauna of Protected Areas-I: Spiders of Vansda National Park, Gujarat. Zoos' Print Journal 18(4): 1079-1083; http:// dx.doi.org/10.11609/JoTT.ZPJ.18.4.1079-83

Patel, B.H. (2003b). A preliminary list of spiders with description of three new species from Parambikulam Wildlife Sanctuary, Kerala. Zoos' Print Journal 18(10): 1207-1212; http://dx.doi.org/10.11609/ JoTT.ZPJ.18.10.1207-12
Platnick, N.I. (2013). The World Spider Catalog, Version 13.5, American Museum of Natural History. Website: <http://research.amnh.org/iz/ spiders/catalog/THERIDIIDAE.html> (Accessed on $2^{\text {nd }}$ June 2013).

Pocock, R.I. (1900). Arachnida. The Fauna of British India, including Ceylon and Burma. Published under the authority of the Secretary of State for India in Council, xii, 279pp.

Rao, K.T., M.P. Raju, I.S.R. Krishna, S.M.M. Javed, M. Siliwal \& C. Srinivasulu (2004). Record of Poecilotheria regalis Pocock, 1899 from Nallamala Hills, Eastern Ghats, Andhra Pradesh. Zoos' Print Journal 19(10): 1668; http://dx.doi.org/10.11609/JoTT.ZPJ.1112.1668

Rao, K.T., D.B. Bastawade, S.M.M. Javed \& I.S.R. Krishna (2006). Description of two new species of spiders of the genus Poecilotheria Simon (Araneae: Theraphosidae) and Tmarus Simon (Araneae: Thomisidae) from Nallamalai Hills, Eastern Ghats, Andhra Pradesh, India. Records of the Zoological Survey of India 106: 49-54.

Schmidt, G. \& P. Klaas (1991). Eine neue Latrodectus-Spezies aus Sri Lanka (Araneida: Theridiidae). Arachnologischer Anzeiger 14: 6-9.

Sebastian, P.A., A.V. Sudhirkumar, M.J. Mathew \& P.D. Samson (2009). Suborder Araneomorphae. pp. 114-396. In: Sebastian, P.A. \& K.V. Peter (eds.). Spiders of India. Universities Press, Hyderabad, India, xxiv+614pp.

Shukla, S. \& V. Gour-Broome (2007). First report of the brown widow spider, Latrodectus geometricus C.L. Koch (Araneae: Theridiidae) from India. Current Science 93(6): 775-777.

Siliwal, M. \& D. Kumar (2001). Rare sighting of poisonous spider Latrodectus hasseltii indicus Simon (Araneae: Theridiidae) in the cotton field of Baroda District, Gujarat. Current Science 81(9): 1170-1171.

Siliwal, M. \& S. Molur (2007). Checklist of spiders (Arachnida: Araneae) of South Asia including the 2006 update of Indian spider checklist. Zoos' Print Journal 22(2): 2551-2597 + web supplement 2551-2597-ixxxiv; http://dx.doi.org/10.11609/JoTT.ZPJ.1509.2551-97

Siliwal, M., S. Molur \& B.K. Biswas (2005). Indian spiders (Arachnida: Araneae): Updated checklist 2005. Zoos' Print Journal 20(10): 19992049; http://dx.doi.org/10.11609/JoTT.ZPJ.1283.1999-2049

Srinivasulu, C. (2000). Giant Wood Spider Nephila maculata (Fabr.) in forested tracts along the river Godavari in Andhra Pradesh. Zoos' Print Journal 15(3): 229-230; http://dx.doi.org/10.11609/JoTT. ZPJ.15.3.229-30

Srinivasulu, C., B. Srinivasulu \& A. Vinodh (2008). Parachute (Tarantula) Spiders of Andhra Pradesh. Biodiversity News of Andhra Pradesh 1(3-4): 4.

Srinivasulu, C., B. Srinivasulu \& M. Siliwal (2004a). Occurrence of Argiope lobata (Pallas, 1772) in Rollapadu Wildlife Sanctuary, Andhra Pradesh. Zoos' Print Journal 19(9): 1625 \& 1625i (web supplement); http://dx.doi.org/10.11609/JoTT.ZPJ.1091a.1625

Srinivasulu, C., B. Srinivasulu \& M. Siliwal (2004b). Sightings of Argiope anasuja Thorell, 1887 and Argiope aemula (Walckenaer, 1842) (Araneae: Araneidae) in Andhra Pradesh, India. Bugs ' $R$ ' All 7(2): 7.

Tikader, B.K. (1987). Handbook of Indian Spiders. Zoological Survey of India, Calcutta, 251pp.

Yoshida, H. (2001). The genus Rhomphaea (Araneae: Theridiidae) from Japan, with notes on the subfamily Argyrodinae. Acta Arachnologica, 50: 183-192. 